\title{
Dampak Eksploitasi terhadap Keaekaragaman Makrozoobhentos di Pesisir Pantai Kalaki Kec. Palibelo Kab. Bima Nusa Tenggara Barat
}

\section{The Impact of Exploitation of Diversity of Macrozoobhentos in Coastal Coast of Kalaki Sub-District Palibelo, Bima District, West Nusa Tenggara}

\author{
M.Noris \\ Program Studi Magister Pendidikan Sains \\ Fakultas Keguruan dan Ilmu Pendidikan, Universitas Sebelas Maret. \\ Jl. Ir. Sutami No.36 A, Pucangsawit, Kec. Jebres, Kota Surakarta, Jawa Tengah 57126 \\ *Corresponding authors: muhammadnoris905@gmail.com
}

\begin{abstract}
Sampling of macrozoobenthos was carried out in the coastal areas of Kalaki, Pallibelo sub-district, Bima, consisting of Station I (the coastal area near the salt ponds) and Station II (the coastal area far from the salt ponds). Determination of the station is done by purposive sampling method. This type of research is a quantitative exploratory survey. The type of data taken is 1) macrozoobhentos data, 2) habitat data (abiotic factors). Data analysis uses the shannon-wiener index ( $\mathrm{H}$ '), the Population Density Index (KP), and the Krebs Uniformity Index (E). The results showed temperature (30-33 oC: 25-28 oC), Ph (6-6.5: 6-6.7), salinity (20-25\%: 27-33\%). Macrozoobenthos found consisted of actinopteri, malacostraca, bivalvia, and atinopterygii classes. The number of macrozoobenthos identified was 153 species consisting of a family of 84 species, 56 species of penaeidae, 4 types of chanidae, 3 types of Arcidae, Mytilidae, Veneridae, Anguillidae of 2 species each. Diversity index $H=1.132$ : 0.952, Uniformity Index Value $(E)=(0.582: 0.489)$, Population Density Value (KP) Scylla sp. 5,143-6,857 and 0.143 for the Pena viridis, Metrix metrix, Anguilla bicolor.
\end{abstract}

Keywords: Macrozoobenthos, Exploitation, Diversity, Coastal

\section{PENDAHULUAN}

Pantai kalaki merupakan pantai berpasir coklat dengan dasar laut landai. Pantai ini tergolong dalam zona intertidal yang merupakan zona dangkal dari samudra yang bersisiran diantara garis pasang naik dan pasang surut. Hal ini ditandai dengan ombak yang relatif kecil sehingga banyak dari nelayan menggunakan pantai ini sebagai tempat budidaya ikan dengan menggunakan karamba. Selain hampir setiap hari aktivitas nelayan pencari ikan dan kepiting bakau di sepanjang bibir pantai kalaki dalam keadaan surut. Banyak dijumpai pula sedimentasi sampah buangan dari aliran sungai terakumulasi dan bertumpuk di pesisir pantai kalaki. Hal demikian dapat mempengaruhi kualitas air dan mengganggu kelimpahan dari makrozoobentos. Air laut merupakan komponen penting komoditas lingkungan kawasan pesisir pantai. Beberapa aktivitas manusia dengan seperti pertumbuhan dan populasi yang tinggi di kawasan pesisir menimbulkan permasalahan bagi kelestarian lingkungan hidup. Kawasan pesisir pantai merupakan kawasan perbatasan antara daratan dan air laut. Kawasan pesisir memiliki nilai strategis berupa sumber daya alam seperti makrozoobentos. Selain pada faktor pertumbuhan dan kepadatan populasi, pembangunan dan lahan industri sebagai bentuk eksploitasi terhadap kawasan pesisir menjadi faktor utama hilangnya sumber daya alam. Sebagaimana yang terjadi pada kawasan pesisir kalaki kecamatan belo kabupaten bima yang dimanfaatkan sebagai tambak garam dan lahan industri minyak tanah. Menurut Mardianto (2014), adanya industri tambak garam pada kawasan pesisir dapat terjadinya pencemaran dan kepunahan biota laut serta rusaknya ekosistem dikawasan pesisir Kalaki Kecamatan Palibelo Kabupaten Bima.

Menurut Showstack (2011), menyatakan bahwa perhitungan akhir untuk keanekaragaman speies laut dapat mencapai 10 kali lipat lebih tinggi dari pada 210.000 bentuk kehidupan biota laut yang saat ini sedang di data tiap tahunnya. Hasil penelitian Hamuna (2018), menunjukan bahwa perubahan baku mutu pH, DO, BODs, sulfid dan kecerahan dapat mempengaruhi kelangsungan hidup dari biota laut. Parameter yang melampaui ambang batas maksium baku mutu berasal dari sumber alami limbah domestik dan aktivitas masyarakat yang eksploratif.

Upaya eksploitasi yang berlebihan yang dilakukan oleh masyarakat dapat berakibat buruk terhadap kelimpahan dan keanekaragaman hayati biota laut. Oleh karena itu, penelitian ini bertujuan untuk mengetahui dampak dari eksploitasi terhadap kelimpahan makrozoobentos dikawasan pesisir pantai kalaki Kecamatan Palibelo, Kabupaten Bima, Nusa Tenggara Barat. 


\section{METODE}

\section{Waktu dan Tempat Penelitian}

Penelitian ini dilaksanakan selama 2 bulan terhitung tanggal 25 Mei - 25 Juni 2020. Lokasi penelitian dan pengambilan sampel makrozoobentos dilaksanakan di kawasan pesisir Pantai Kalaki Kecamatan Palibelo Kabupaten Bima yang dibagi menjadi 2 stasiun yakni stasiun I (daerah pesisir dekat tambak garam) dan stasiun II (daerah pesisir jauh dari tambak.

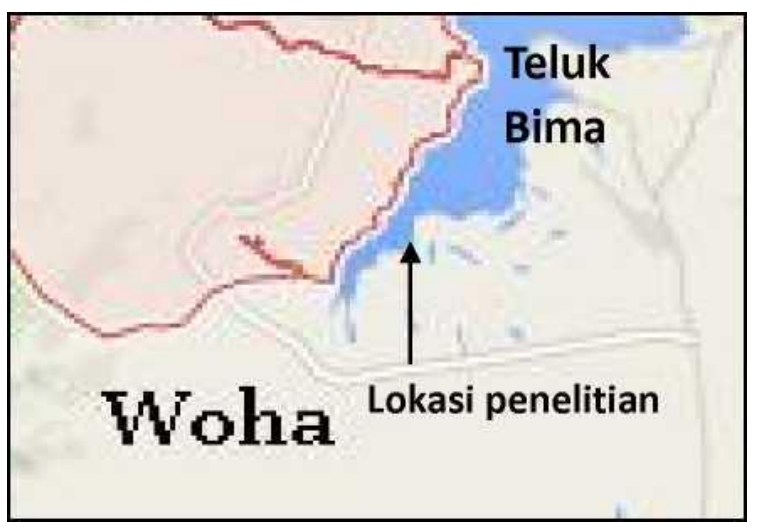

Gambar 1. Lokasi Penelitian

\section{Teknik Pengambilan Data}

Penentuan stasiun dilakukan secara Purposive Sampling Method. Jenis penelitian ini adalah Survey Eksploratif Kuantitatif. Jenis data yang diambil adalah: 1) data makrozoobentos yang meliputi Class, Ordo, Familia dan Spesies. 2) Data Habitat (faktor abiotik) yang meliputi: Tanggal Dan Waktu Pengambilan Data, Nama Lokasi, Suhu Air Laut, pH, salinitas, DO, warna, kekeruhan air laut serta sedimen (substrat).

\section{Teknik Analisis Data}

Analisis data menggunakan Indeks Shannon-Wiener (H'), Indeks Kepadatan Populasi (KP), dan Indeks Keseragamana Krebs (E').

\section{HASIL DAN PEMBAHASAN}

\section{Faktor Abiotik Dipesisir Pantai Kalaki Kecamatan Palibelo Kabupaten Bima Nusa Tenggara Barat}

Hasil pengukuran terhadap faktor abiotik dikawasan pesisir Pantai Kalaki Kecamatan Belo Kabupaten Bima Nusa Tenggara Barat ditunjukkan pada tabel 1 dibawah ini.

Tabel 1. Faktor Abiotik Pesisir Kalaki Kecamatan Palibelo Kabupaten Bima Nusa Tenggara Barat.

\begin{tabular}{cccc}
\hline No. & Parameter & Stasisun 1 & Stasiun 2 \\
\hline 1 & Suhu $\left({ }^{\circ} \mathrm{C}\right)$ & $30-33$ & $25-28$ \\
2 & $\mathrm{p}^{\mathrm{h}}$ & $6.0-6.5$ & $6.0-6.7$ \\
3 & Salinitas $(\%)$ & $30-35$ & $35-40$ \\
4 & DO $(\mathrm{mg} / \mathrm{l})$ & $2.4-3$ & $3.5-4$ \\
5 & Sedimen/ substrat & Karang dan Pasir lumpur & Karang dan pasir lumpur \\
6 & Kekeruhan & Tinggi & Sedang \\
7 & Warna & Coklat & Coklat kehijauan
\end{tabular}

Berdasarkan data pada tabel 1, faktor abiotik pada pengukuran suhu air laut pada kawasan pesisir Pantai Kalaki Kecamatan Palibelo Kabupaten Bima pada stasiun I berkisar 30 - 33 oC sedangkan pada stasiun II berkisar 25-28 oC. suhu sangat berpengaruh terhadap pertumbuhan dan distribusi makrozoobentos.

Menurut Hawkes (1978) menyatakan bahwa suhu untuk perkembangan makrozoobentos berkisar $28-31{ }^{\circ} \mathrm{C}$, dan suhu kritis berkisar $35-40{ }^{\circ} \mathrm{C}$. karena dapat menyebabkan kematian dan meningkatkan mortalitas makrozoobentos. Berbeda dengan Hasil Penelitian Izzah (2016), meyatakan bahwa taraf suhu optimum untuk pertumbuhan makrozoobentos berkisar $2535{ }^{\circ} \mathrm{C}$. dengan demikian suhu pada stasiun I dan II merupakan suhu stabil, karena $<35{ }^{\circ} \mathrm{C}$ sesuai dengan suhu optimum. Menurut Patty (2018), menyatakan bahwa suhu air dipenguruhi oleh intensitas cahaya, kondisi atmosfir, cuaca dan iklim serta beberapa faktor geografis dan dinamika arus.
$\mathrm{pH}$ atau derajat keasaman pada staisun I berkisar 6-6.5 sedangkan pada staisiun II berkisar 6-6.7. Menurut Izzah (2016) mengatakan bahwa biota air pada umumnya sensitif akan suatu perubahan. Organisme benthos menyukai $\mathrm{pH}$ berkisar 78.5 pada lingkungan hidupnya, jika $\mathrm{pH}<7$, maka telah terjadi penurunan organisme benthos. Sedangkan hasil penelitian Asry (2014) menyatakan bahwa kemampuan bertahan hidup makrozoobentos pada kisaran $\mathrm{pH}$ 7-8. Kondisi pada stasiun I dan II mengindikasikan bahwa telah terjadi pencemaran ringan terhadap kualitas biota laut. Sedangkan menurut Hamuna (2018), variasi nilai Ph dapat mempengaruhi biota dalam suatu perairan. Hal ini dapat mengurangi produktivitas dari kelimpahan makrozoobentos sebagai komponen penting dalam ekosistem biota laut. 
Pengukuran salinitas air laut kawasan pesisisir kalaki diperoleh pada stasiun I berkisar 20-25 \% sedangkan pada stasiun II berkisar 27-33 \%. Angka tersebut

menunjukkan bahwa salinitas air laut yang menjadi habitat utama benthos terdeteksi memiliki salinitas yang lebih rendah dari standar salinitas lautan yang berkisar 30$40 \%$. Penurunan dari salinitas akan menurunkan kemampuan pertumbuhan dan perkembangan makrozoobentos (Izzah, 2016). Sedangkan peningkatan salinitas terjadi akibat adanya proses penguapan air yang dapat mengurangi volume air sehingga meningkatkan konsentrasi garam-garam terlarut (Rukminasari, 2014). Menurut Kevrekidis (2004), menyatakan bahwa akibat dari salinitas rendah berdampak langsung terhadap indeks keanekaragaman spesies. Hal ini mengindikasikan pengaruh salinitas terhadap kelimpahan biota laut.

Berdasarkan hasil pengukuran DO (Dissolved Oxygen) pada stasiun I berkisar 2.4-3.0 mg/l, sedangkan pada stasiun II berkisar 3.5-4.0 mg/l. Menurut Saparinto (2007) kadar DO optimum yang dibutuhkan makrozoobentos berkisar 4.00-6.00 mg/l. Semakin besar kadar Oksigen terlarut dalam suatu ekosistem, menunjukkan semakin baiknya kehidupan makrozoobentos yang mendiaminya. Pada ke-2 stasiun tersebut mengindikasikan bahwa jumlah kadar oksigen terlarut menunjukkan bahwa Tabel 2. Data Keanekaragaman Makrozoob Palibelo Kabupaten Bima ekosistem pesisir kalaki mengalami pencemaran rendah yang dibuktikan dengan taraf oksigen terlarut $<4.00 \mathrm{mg} / \mathrm{l}$.

\section{Keanekaragaman Makrozoobentos}

Berdasarkan hasil pengamatan pada pesisir Pantai Kalaki Kecamatan Palibelo, Kabupaten Bima, Nusa Tenggara Barat. Keanekaragaman makrozoobentos dapat dilihat pada tabel 2 dibawah ini:

Tabel 2. Keanekaragaman Makrozobentos

\begin{tabular}{|c|c|c|c|c|c|c|c|c|}
\hline \multicolumn{9}{|c|}{ Jumlah Spesies } \\
\hline Familia & Spesies & Substrat & Stasisun & Stasiun & $\mathbf{N}$ & $\mathbf{P i}$ & Ln Pi & Pi Ln Pi \\
\hline & & & 1 & 2 & & & & \\
\hline Chanidae & Chanos Sp. & Air Laut & 3 & 1 & 4 & 0.026 & -3.644 & -0.095 \\
\hline Penaeidae & P. Semisulcatus & Pasir & 24 & 32 & 56 & 0.366 & -1.005 & -0.368 \\
\hline Portunidae & Scylla Sp. & Karang & 36 & 48 & 84 & 0.549 & -0.600 & -0.329 \\
\hline \multirow{2}{*}{ Arcidae } & Anadara & Pasir & \multirow{2}{*}{2} & \multirow{2}{*}{1} & \multirow{2}{*}{3} & & & \\
\hline & Granosa & Lumpur & & & & 0.020 & -3.932 & -0.077 \\
\hline Mytilidae & Perna Viridis & Karang & 1 & 1 & 2 & 0.013 & -4.337 & -0.057 \\
\hline Veneridae & Metrix Metrix & Karang & 1 & 1 & 2 & 0.013 & -4.337 & -0.057 \\
\hline \multirow[t]{2}{*}{ Anguilllidae } & Anguilla Bicolor & Karang & 1 & 1 & 2 & 0.013 & -4.337 & -0.057 \\
\hline & TOTAL & & & & 153 & & & 1.040 \\
\hline
\end{tabular}

Berdasarkan Tabel 2 diatas, terdapat 8 spesies yang dijumpai dalam kawasan pesisir kalaki di berbagai substrat seperti air laut, pasir, karang dan lumpur. Makrozoobentos yang ditemukan terdiri dari Class Actinopteri (Chanos sp.), Malacostraca (P. semisulcatus, Scylla sp.), Bivalvia (Anadaragranosa, Pena viridis, Metrix metrix) dan Actinopterygii (Anguilla Bicolor). Jumlah makrozoobentos yang teridentifikasi mencapai 153 spesies dengan Taraf Indeks Keanekaragaman Jenis 1.040 yang terdiri atas Familia Portunidae 84 jenis, Penaeidae 56 jenis, Chanidae 4 jenis, Arcidae 3 jenis, Mytilidae, Veneridae, Anguillidae masing masing 2 jenis. Menurut Ji (2015), menyatakan bahwa makrofit heterogenitas pada suatu habitat menjadi alasan utama keberadaan makrozoobentos karena menyediakan ragam substrat sebagai tempat memperoleh makanan, tempat tinggal, dan reproduksi.

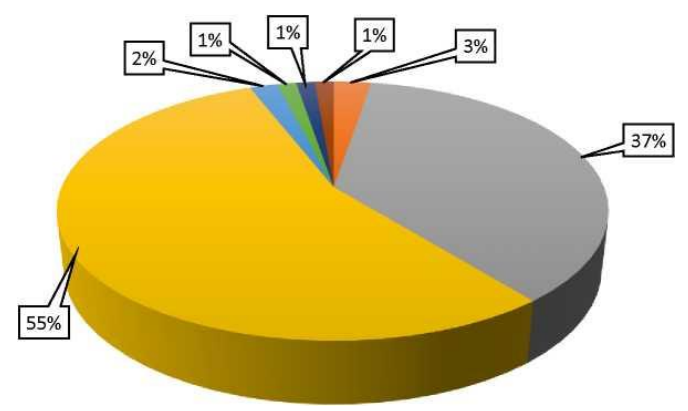

Gambar 2. Data Jumlah Makrozoobentos Yang Teridentifikasi Dikawasan Pesisir Kalaki Kecamatan Belo Kabupaten Bima Nusa Tenggara Barat. 


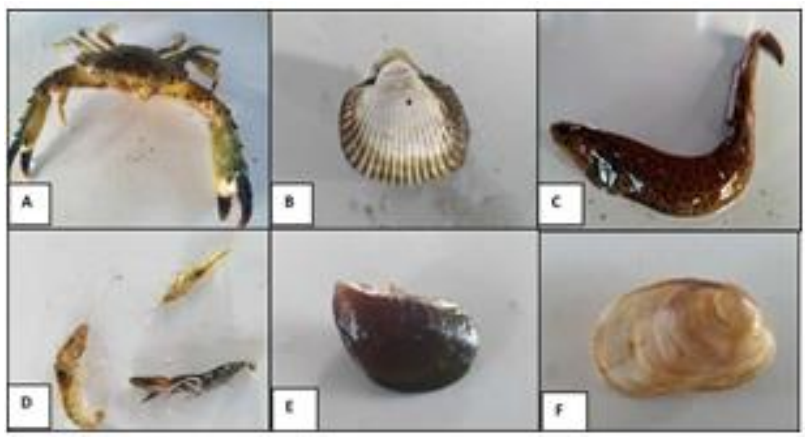

Gambar 3. Data Dokumentasi Makrozoobentos Yang Teridentifikasi Dikawasan Pesisir Kalaki Kecamatan Belo Kabupaten Bima Nusa Tenggara Barat A. Scylla sp., B. Anadara granosa E, C. Anguilla bicolor F, D. P. Semisulcatus, E. Perna viridis, F. Metrix metrix)

Presentase jumlah makrozobentos yang teridentifikasi dikawasan pesisir pantai kalaki terdiri dari Spesies Scylla
Sp. sebesar $55 \%$, P. semisulcatus $37 \%$, Chanos sp. Sebesar $3 \%$, Anadara granosa sebesar $2 \%$, dan Metrix metrix, Anguilla bicolor, dan Perna viridis masing-masing sebesar $1 \%$.

Pada ordo Bivalvia terdiri atas Anadara granosa, Metrix metrix, dan Perna viridis. Menurut Islami (2013) kelompok Familia Bivalvia memiliki rentang toleransi terhadap lingkungan. Kondisi lingkungan yang sesuai dengan taraf hidup Bivalvia adalah $24-31{ }^{\circ} \mathrm{C}$ dan $15-35 \%$.

Pada umumnya kelas Bivalvia dijumpai pada sedimen lumpur pasir namun pada penelitian ini bivalvia dijumpai di karang. Distribusi spesies dominan makrozoobentos juga dapat dilihat dari spesifiksi lokasi tingkat trofik, makrofit dan karakteristik sedimen. dikawasan pesisir pantai kalaki bahwasannya sedimentasi dan substrat makrozoobentos didominasi oleh karang dan pasir lumpur. Hal ini menunjukkan tingkat pencemaran pada biota laut yang mempengaruhi tingkat keanekaragaman dari makrozoobentos (Ji, 2015).

Tabel 3. Data Indeks Kepadatan Populasi (KP), Indeks Keanekaragaman (H'), dan Indeks

\begin{tabular}{|c|c|c|c|c|c|c|c|c|}
\hline \multirow{2}{*}{ Spesies } & \multicolumn{8}{|c|}{ Stasiun } \\
\hline & $\begin{array}{l}\text { Jumlah } \\
\text { individu }\end{array}$ & $\mathbf{H}^{\prime}$ & $\mathbf{E}$ & KP & $\begin{array}{l}\text { Jumlah } \\
\text { individu }\end{array}$ & $\mathbf{H}^{\prime}$ & $\mathbf{E}$ & KP \\
\hline chanos sp. & 3 & & & 0.429 & 1 & & & 0.143 \\
\hline p. semisulcatus & 24 & & & 3.429 & 32 & & & 4.571 \\
\hline scylla sp. & 36 & & & 5.143 & 48 & & & 6.857 \\
\hline anadara granosa & 2 & 1.132 & 0.582 & 0.286 & 1 & 0.952 & 0.489 & 0.143 \\
\hline perna viridis & 1 & & & 0.143 & 1 & & & 0.143 \\
\hline metrix metrix & 1 & & & 0.143 & 1 & & & 0.143 \\
\hline anguilla bicolor & 1 & & & 0.143 & 1 & & & 0.143 \\
\hline
\end{tabular}

Berdasarkan tabel 3 diatas, jumlah kepadatan populasi pada masing-masing stasiun meiliki taraf yang berbeda. Pada stasiun I jumlah kepadatan populasi tertinggi yakni pada Scylla Sp. dengan Indeks Kepadatan Populasi sebesar 5.143, P. semulcatus sebesar 3.429, Chanos sp. Sebesar 0.429, Anadara granosa sebesar

286, dan Pena viridis, Metrix metrix, Anguilla bicolor masing-masing sebesar 0.143. sedangkan pada stasiun II Scylla Sp. sebesar 6.857, P. semulcatus sebesar 4.571, Chanos sp., Anadara granosa , Pena viridis, Metrix metrix, Anguilla bicolor masing- masing sebesar 0.143. ada perbedaan yang signifikan antara kedua stasiun dalam indeks kepadatan populasi.

Indeks keanekaragaman (H') pada dua staisun memiliki taraf indeks yang cukup signifikan, dimana pada stasiun I indeks keanekaragaman sebesar 1.132 sedangkan pada stasiun II sebesar 0.952. Menurut Dalfsen (2020), menyatakan bahwa gangguan dalam skala kecil dalam morfologi dasar laut dan komposisi sedimen dapat menghasilkan efek jangka pendek terhadap komunitas bentik. Namun, gangguan yang lebih besar terutama disebabkan oleh komposisi sedimen dapat menyebabkan kerusakan jangka panjang terhadap biota laut komunitas pesisir bentik sublittoral. Menurut persamaan ShannonWiener (H') Indeks Keanekaragaman berkisar 1-2 tergolong dalam keanekakaraman tinggi. Berdasarkan tabel 3 pada kedua stasiun memiliki Indeks Keanekaragaman tergolong tinggi yakni 0.489-1.32.

Indeks keseragaman pada stasiun I sebesar 0.582 sedangkan pada stasiun II sebesar 0.489. Hal ini sejalan dengan Menurut Fachrul (2007) dalam Izzah (2016) menyatakan bahwa kategori Indeks keanekaragaman berdasarkan persamaan Shanon-Wiener dinyatakan sangat tinggi dan tidak tercemar berkisar $>3$, tinggi dan tercemar ringan berkisar antara 2-3, rendah dan setengah tercemar berkisar antara $1-2$, sangat rendah dan tercemar berat berkisar <1. Menurut Odum (1993) menyatakan bahwa Indeks Keseragaman Krebs (E') berkisar 0

Apabila nilai indeks mendekati 0, artinya keseragaman rendah karena adanya jenis lain yang sangat mendominasi, dan apabila mendekati nilai 1 berarti keseragaman tinggi Grafik 2. Data Indeks Kepadatan Populasi (KP) karena 
menunjukkan tidak ada jenis yang mendominasi pada habitat tersebut.

Menurut Indriyanto (2010) menyatakan bahwa indeks keanekaragaman dan keseragaman memiliki korelasi. Angka Indeks Keanekaragaman (H') yang semakin tinggi memungkinkan terjadinya angka Indeks Keseragaman rendah karena keragaman dalam populasi atau ekosistem baik secara genetik dan jenis pada suatu habitat berbeda serta tidak seragam. Berdasarkan hasil dari tabel 3 di perlihatkan bahwa H' sekitar $1.132 ; 0.582$ dan E' 0.952 ; 0.489 .

Dengan demikian pada kawasan Pesisir Pantai Kalaki Kecamatan Palibelo Kabupaten Bima Indeks Keanekaragaman yang tergolong tinggi dan indeks keseragaman tergolong tinggi ( $>1$ ).

Hasil Penelitian Keli (2019) menunjukkan bahwa akibat adanya upaya ekspolitasi, aktivitas manusia telah serius mengganggu habitat macrozoobentos dan menyebabkan penurunan keanekaragaman macrozoo bentos. Oleh karena itu, restorasi habitat dan konservasi makrozoobentos guna terpeliharanya keanekaragaman dan keseragaman biota laut.

Bau, warna dan kekeruhan permukaan air laut juga menjadi indikator penting sebagai pengukuran tingkat pencemaran ekosistem pesisir pantai kalaki. Warna coklat kehitaman pada kedua stasiun mengindikasikan bahwa ekosistem pesisisr kalaki mengalami pencemaran tergolong sedang dengan tingkat toleransi kehidupan biota air laut relatif tinggi. Keberadaan makrozoobentos tidak terlepas dari factor abiotik yang mendukung struktur komponen penting dalam ekosistem air laut. Hal ini mendukung pertumbuhan dan perkembangan dari makrozoobentos yang mendiami suatu ekosistem. Semakin tinggi tingkat pencemaran maka semakin rendah indeks keanekaragaman dan indeks keseragaman dari spesies makrozoobentos. Semakin tinggi kepadatan suatu populasi maka semakin tinggi tingkat keanekaragaman hayati (H'). Tingkat eutrofikasi juga dapat menjadi faktor keanekaragaman makrozoobentos, semakin tinggi tingkat eutrofikasi maka semakin rendah keanekaragaman makrozoobentos dan beberapa spesies memiliki kemampuan toleransi terhadap oksigen terlarut (Gong, 2001).

Menurut Xie (2003), menyatakan bahwa kelimpahan makrozoobentos dipengaruhi oleh beberapa faktor yang paling berpengaruh diantaranya adalah kedalaman air, $\mathrm{pH}$, konduksivitas, dan $\mathrm{CA}^{2+}$, adalah faktor lingkungan yang signigfikan mempengaruhi pola macrozoobentos.

\section{KESIMPULAN}

Berdasarkan hasil penelitian yang dilakukan di kawasan pesisir pantai kalaki kecamatan belo kabupaten bima nusa tenggara barat, adapun kesimpulan yang diperoleh yakni sebagai berikut:

Jumlah makrozoobentos yang teridentifikasi mencapai 153 Spesies yang terdiri atas Familia Portunidae 84 jenis, Penaeidae 56 jenis, Chanidae 4 jenis, Arcidae 3 jenis, Mytilidae, Veneridae, Anguillidae masing masing 2 jenis
Jumlah Indeks Keanekaragaman (H') dikawasan pesisir kalaki pada stasiun I indeks keanekaragaman sebesar 1.132 sedangkan pada stasiun II sebesar 0.952 . tergolong keanekaragaman tinggi

Nilai Indeks keseragaman (E) pada stasiun I sebesar 0.582 sedangkan pada stasiun II sebesar 0.489 tergolong keseragaman tinggi karena mendekati angka 1.

Nilai Kepadatan Populasi (KP) tertinggi yakni Scylla Sp. dengan Indeks Kepadatan Populasi sebesar 5.143 ; 6.857 dan terendah Pena viridis, Metrix metrix, Anguilla bicolor sebesar 0.143 .

\section{REFERENSI DAN SITASI}

Asry. 2014. Komunitas Makrozoobentos Sebagai Bioindikator Kualitas Perairan Kecamatan Pantai Labu Kabupaten Deli Serdang. Medan: Universitas Sumatera Utara.

Dalfsen. 2020. Macrobenthos Data From The Doggerbank-2000. Institute For Marine Resources And Ecosystem Studies; Vestiging Den Helder, The Netherlands.Http://Ipt.Vliz.Be/Euro bis/Resource?R=Nsbp Vandalfsen

Gong, Zhijun; Xie Ping. 2001. Impact Of Eutrophication On Biodiversity Of The Macrozoobenthos Ommunity In A Chinese Shallow Lake. Journal Of Freshwater Ecology. $\quad 16 \quad$ (2):

178.Https://Doi.Qrg/10.1080/02705 060.2001 .9663802

Hawkes. 1978. River Zonation And Classification In River Ecology, Ed. By. Departement Of Nutrition And Food Science

Hamuna, Baigo. 2018. Kajian Kualitas Air Laut Dan Indes Pencemaran Berdasarkan Parameter Fisik-Kimia Diperairan Distrik Depare, Jayapura. JurnalIlmu Lingkungan. 16 (1): 3543.

Islami. 2013. Pengaruh Suhu Dan Salinitas Terhadap Bivalvia. Oseana: 1-10.

Izzah, A. Nisrina; Roziaty, Efri. 2016. Keanekaragaman Makrozoobentos Di Pesisir Panta Desa Panggung

Kecamatan Kedung Kabupaten Jepara. Jurnal Bioeksperimen. 2 (2): 140-148.

Ji, Lei; Et Al. 2015. Spatial Variation In Nutrient Excretion By

Macrozoobenthos In A Chinese Large Shallow Lake (Lake Taihu). Journal Of Freshwater Ecology. 30 (1):169-180.

Https://Doi.Qrg/10.1080/02705060.

2014.997816

Kevrekidis, Theodoros. 2004. Seasonal Variation Qf The Macrozoobenthic Community Structure At Low Salinitie In A Mediterranean Lagoon (Monolimni Lagoon, Northern Aegean). Journal International Review Of Hydrobiology. 89 (4): 407-425.

Https://Doi.Qrg/10.1002/Iroh.20031

0703

Mardianto, D. 2014. Potensi Sumberdaya Pesisir Kabupaten Jepara. Yogyakarta: Gdjah Mada University Press.

Qdum. 1993. Dasar-Dasar Ekologi Umum. Yogyakarta: Gadjah Mada 
University Press.

Patty, I. Simon. 2018. Kondisi Suhu, Ph, dan Qksigen Terlarut di Perairan Terumbu Karang Ternate, Tidore dan Sekitarnya. Jurnal Ilmu Kelautan Kepulauan. 1 (2): $1-10$.

Rukminsari, Nita. 2014. Pengaruh Derajat Keasaman Air Laut Terhadap Konsentrasi Kalsium Dan Laju Pertumbuhan Halimeda sp. Jurnal Ilmu Kelautan Dan Perikanan. 24 (1): 28-34.

Saparinto, Cahyo. 2007. Pendayagunaan Ekosistem Mangrove. Semarang: Dahara Prize. Hal: 199

Showstack, Randy. 2011. Marine Life Report Highlights Need For Besaline Konledge. Journal Advancing Earth And Space Science. 84 (46): 504. Https://Doi.Org/10.1029/2003EQ46 0005

Xie, Zhical; Et Al.2003. Structure Qf Macrozoobenthos Qf The East Dongting Nature Reserve, With Empharis Qn Relationships With Enviromental Variables. Journal of Freshwater Ecology. 18 (3);405- 413.Https://Doi.Qrg/10.1080/02705 060.2003 .9663976 . 